\begin{tabular}{lc} 
Sharif University of Technology \\
Scientia Iranica \\
SCIENTIA & Transactions B: Mechanical Engineering \\
IRAN I CA & \\
\hline
\end{tabular}

Research Note

\title{
Thermodynamic analysis of a novel solar trigeneration system
}

\author{
V. Beygzadeh ${ }^{a, *}$,Sh. Khalilarya ${ }^{a}$, I. Mirzaee ${ }^{a}$, Gh. Miri ${ }^{b}$, and V. Zare \\ a. Department of Mechanical Engineering, Faculty of Engineering, Urmia University of Technology, Urmia, P.O. Box 57155-419, \\ Iran. \\ b. Department of Business Management, National Iranian Oil Refining \& Distribution Company, Tehran, Iran.
}

Received 4 February 2019; received in revised form 11 July 2019; accepted 22 October 2019

\author{
KEYWORDS \\ Energy efficiency; \\ Exergy efficiency; \\ Solar loop heat pipe \\ system; \\ Regenerative organic \\ Rankine cycle; \\ Combined cooling; \\ Heating and power; \\ Solar energy.
}

\begin{abstract}
Loop Heat Pipes (LHPs) are devices with high efficiency which can be used in solar systems. The main objectives of this research are to propose a novel Solar Combined Cooling, Heating, and Power (SCCHP) system based on LHP evaporator and present a thermodynamic analysis to improve the utilization of LHP in solar systems. Moreover, a parametric analysis was carried out to investigate the effect of key variable parameters on the system performance for three operation modes namely solar mode, solar and storage mode, and storage mode. The results showed that the main source of exergy destruction for both solar mode and the solar and storage mode was the solar LHP evaporator and for the storage mode, was the hot storage tank. The energy efficiency of the proposed system for the solar mode, solar and storage mode, and storage mode was $70.52 \%, 72.09 \%$, and $64.77 \%$. Furthermore, the exergy efficiency of the proposed system for the solar mode, solar and storage mode, and storage mode was $12.36 \%, 14.78 \%$, and $47.45 \%$, respectively.
\end{abstract}

(C) 2021 Sharif University of Technology. All rights reserved.

\section{Introduction}

The use of locally available renewable resources all over the world is gaining significance and it ensures sustainable development and security of the energy supply [1]. Among renewable energy resources, solar energy has drawn considerable attention due to its nonpolluting character and inexhaustible supply [2]. It can be exploited by either thermal collectors or photovoltaic (PV) panels for heat or electricity pro-

\footnotetext{
*. Corresponding author.

E-mail addresses: v_beygzadeh89@ms.tabrizu.ac.ir (V.

Beygzadeh); sh.khalilarya@urmia.ac.ir (Sh. Khalilarya); i.mirzaee@urmia.ac.ir (I. Mirzaee);

gholamreza.miri@gmail.com (Gh.Miri); v.zare@uut.ac.ir (V. Zare)
}

doi: $10.24200 /$ sci.2019.52866.2922 duction [3]. Solar energy is a plentiful and easyto-use energy source that can be transformed either to electricity or useful heat [4]. Combined Cooling, Heating, and Power (CCHP) and Combined Heating and Power (CHP) systems are generally used as energysaving methods for both fossil and renewable energies [5]. To decrease fossil fuel utilization, solar-based systems should be designed for CCHP systems [6]. In recent years, unlike conventional energy sources, these systems have attracted many more customers and emerged as a more sustainable energy solution [7]. The main disadvantages of PV solar systems are their limited availability on the market, high initial cost, occupation of a relatively large area for installation, and high dependence on technology development [8]. Table 1 presents an overview and a comparison of Concentrated Solar Power (CSP) technologies [7].

While conventional PV and solar thermal systems 
Table 1. Overview and comparison of Concentrated Solar Power (CSP) technologies.

\begin{tabular}{|c|c|c|c|c|}
\hline CSP type & $\begin{array}{c}\text { Parabolic } \\
\text { troughs }\end{array}$ & $\begin{array}{c}\text { Linear fresnel } \\
\text { reflectors }\end{array}$ & $\begin{array}{l}\text { Solar } \\
\text { towers }\end{array}$ & $\begin{array}{c}\text { Solar towers } \\
\text { parabolic dish }\end{array}$ \\
\hline $\begin{array}{l}\text { Annual solar } \\
\text { to electricity } \\
\text { efficiency }(\%)\end{array}$ & $11-16$ & 13 & $7-20$ & $12-25$ \\
\hline Temperatures $\left({ }^{\circ} \mathrm{C}\right)$ & $350-550$ & 390 & $250-565$ & $550-750$ \\
\hline Advantages & $\begin{array}{l}\text { 1- The most mature } \\
\text { CSP technology } \\
\text { 2- Heat production } \\
\text { at higher } \\
\text { temperatures }\end{array}$ & $\begin{array}{l}\text { 1- More concentration } \\
\text { of sunlight } \\
\text { 2- Cheaper than the } \\
\text { parabolic through } \\
\text { collectors }\end{array}$ & $\begin{array}{l}\text { 1- Enhanced efficiency } \\
\text { 2- Electricity generation } \\
\text { in the absence of the } \\
\text { sun }\end{array}$ & $\begin{array}{l}\text { 1- Higher efficiency } \\
\text { 2- The most efficient } \\
\text { systems }\end{array}$ \\
\hline Disadvantages & $\begin{array}{l}\text { Restriction of the } \\
\text { output to moderate } \\
\text { steam as a result of } \\
\text { using oil-based heat } \\
\text { transfer media }\end{array}$ & $\begin{array}{l}\text { 1- Less efficient } \\
\text { 2- Difficult to integrate } \\
\text { storage capacity into } \\
\text { their design }\end{array}$ & $\begin{array}{l}\text { 1- Economically justified } \\
\text { 2- Need for a large area } \\
\text { of land } \\
\text { 3- Daily maintenance }\end{array}$ & $\begin{array}{l}\text { 1- High cost } \\
\text { 2- Lack of flexibility } \\
\text { 3- Need for a large } \\
\text { number of equipments } \\
\text { for heat transfer }\end{array}$ \\
\hline
\end{tabular}

have their advantages and disadvantages, the Loop Heat Pipes (LHPs) enjoy several advantages, as listed in the following:

- They do not contain any mechanically movable parts and do not consume any additional energy [9];

- Their capacity may reach thousands in watts [9];

- Application of LHPs in energy-efficient systems to the recovery of low potential heat is highly probable [9];

- They are simple devices with no moving parts and can transfer large quantities of heat over long distances [10];

- They increase the life expectancy of the solar system because they can eliminate the freezing and corrosion phenomena occurring in the Solar Loop Heat Pipe Systems (SLHPS).

Shafieian et al. [11] reviewed several strategies to improve the thermal performance of heat pipe solar collectors in solar systems. They also evaluated the performance of a heat pipe solar water heating system [12]. Allouhi et al. [13] studied the forced circulation solar water heating system using heat pipe flat plate collectors. $\mathrm{Li}$ and Sun [14] carried out performance optimization and benefit analysis of a PV loop heat pipe/solar-assisted heat pump water heating system. Diallo et al. [15] carried out an energy performance analysis of a novel solar Photovoltaic Thermal (PVT) LHP by employing a micro channel heat pipe evaporator and a Phase Change Material (PCM) triple heat exchanger. Lu and Wang [16] carried out a thermodynamic performance analysis of Solar Combined Cooling, Heating, and Power (SCCHP) systems. Hands et al. [17] conducted a performance analysis of an SCCHP system in a building. They showed that the heat obtained from solar energy contributed consistently to reducing gas usage. Wang et al. [18] performed a thermodynamic performance analysis and optimization of an SCCHP system. They indicated that the integration of solar PV into the CCHP system would considerably improve the exergy efficiency. Yuksel et al. [19] performed a thermodynamic analysis of a novel solar system and showed that an increase in the Solar Radiation Intensity (SRI), temperature of the inner surface of absorber pipes, and concentration of ammonia in working fluid mixture had positive effect on the produced electricity. Azad [20] carried out an experimental analysis of thermal performance of solar collectors with different numbers of heat pipes. Li and Sun [21] carried out an operational performance study on a solar system. Jouhara et al. [22] reviewed heat pipe-based systems and pointed to the high efficiency of heat pipes as a passive heat transfer technology as the reason for their significant popularity. They also investigated the performance of a heat pipe-based solar system in district heating applications [23]. Long et al. [24] studied the application of the building integrated heat pipe systems in Hong Kong. He et al. [25] performed a theoretical investigation of the thermal performance of a novel LHP-based heat pump water heating system. Zhang et al. [26] scrutinized the characteristics of a solar system. They indicated that lower SRI, lower air temperature, higher air velocity, and smaller cover numbers brought about 
enhanced electrical efficiency while reducing thermal efficiency for the system. Chaudhry et al. [27] reviewed heat pipe systems for heat recovery and renewable energy applications. Maydanik [28] reviewed LHPs and suggested that LHPs were highly efficient heat transfer devices capable of transferring considerable heat flows over great distances.

The amount of solar radiation reaching the earth's surface varies depending on the geographic location, time of day, season, local landscape, and local weather [29]. The world has direct normal irradiation levels of $41.67-416.7 \mathrm{~W} / \mathrm{m}^{2}$ per day [30]. Thus, solar power can be harnessed using LHP-based solar systems. Although LHPs are simple and efficient heat transfer devices used in energy-efficient systems, no studies, according to the literature, have been conducted on the thermodynamic analysis of LHP-based energy systems.

In this study, a novel SCCHP system equipped with Solar Loop Heat Pipe Evaportor (SLHPE), an auxiliary pump, an absorption chiller, two evaporators, two storage tanks, a storage pump, a Storage Heat Exchanger (STHEX), a Regenerative Organic Rankine Cycle (RORC) turbine, an electrical generator, a Heating Process Heat Exchanger (HPHEX), a regenerator, a Domestic Water Heater (DWH), a Domestic Water Preheater (DWPH), and a RORC pump were thermodynamically modeled and assessed through energy and exergy analyses in three operation modes. In particular, the above-mentioned model was applied and tested in Tabriz, Iran. The main objectives of the present study are to better understand the functionality of the proposed system and propose a new, efficient, and sustainable solar thermal system. To this end, the following steps were taken into account:
- Model and simulate the SCCHP system;

- Validate each part of the model and simulation;

- Perform energy and exergy analyses of the SCCHP system;

- Perform a parametric study to determine the effect of major design parameters on the SCCHP system performance.

The main novelties of the present study lie in its analysis of the performance of a forced circulation SLHPS in a solar trigeneration system, utilization of new collector designs under real operational conditions, and consideration of a new way to incorporate the LHP operation principle into an SLHPS.

\section{Material and methods}

In this section, the specifications of the SCCHP system and its components for three operation modes are introduced.

\subsection{System description}

Figure 1 indicates the schematics of the proposed system.

The SCCHP system uses solar energy to evaporate working fluid (toluene in this study with the thermodynamic properties listed in Table 2) through the SLHPE, which drives the RORC evaporator, and vaporize the working fluid ( $n$-hexane in this study with the thermodynamic properties listed in Table 2).

After leaving the RORC evaporator, $n$-hexane superheated vapor enters the turbine and following its passage through the turbine, the waste heat from the RORC is employed to produce process hot water and cooling and consequently, it passes through the DWH

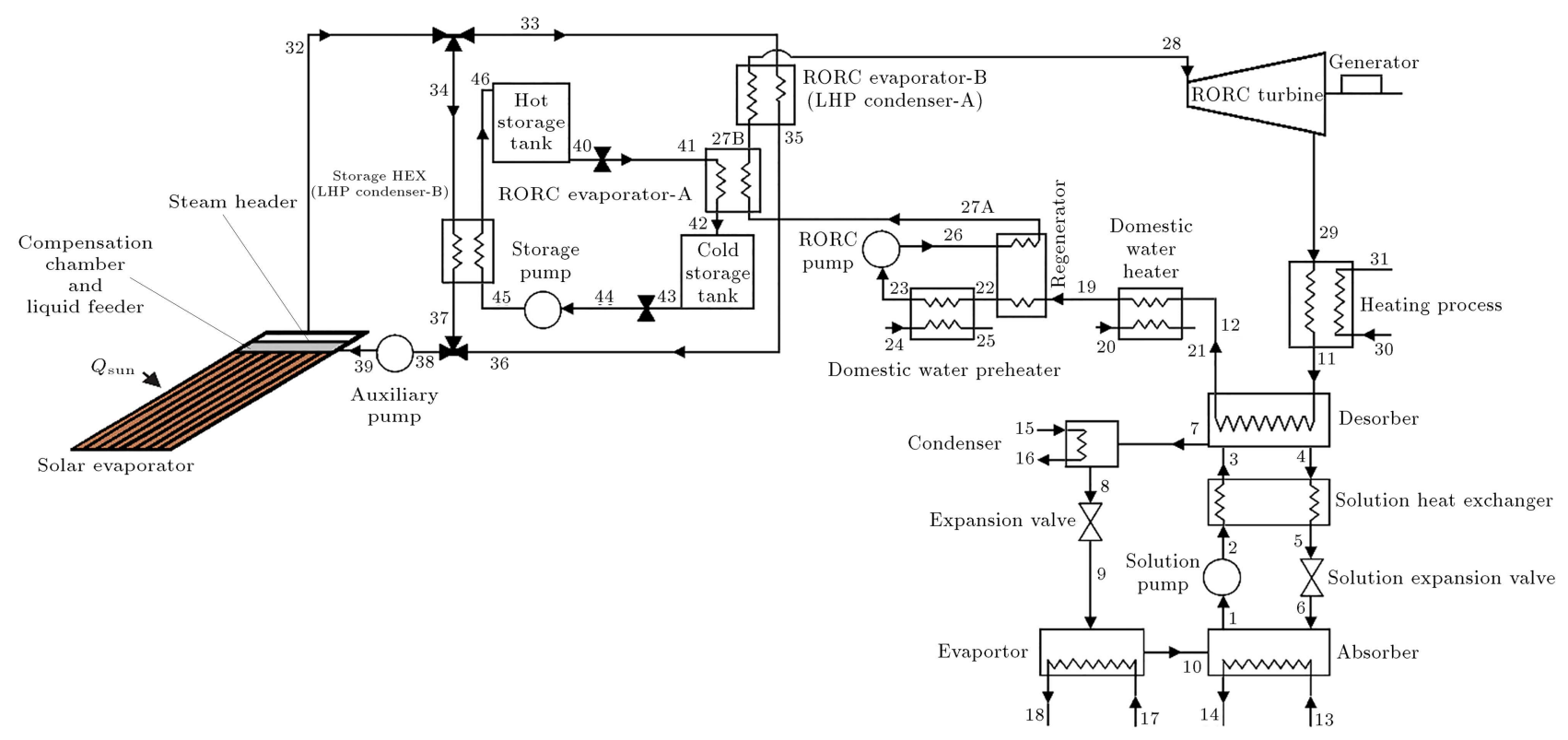

Figure 1. The schematic of the Solar Combined Cooling, Heating, and Power (SCCHP) system. 
Table 2. Properties of working fluids for the Solar Combined Cooling, Heating, and Power (SCCHP) system.

\begin{tabular}{|c|c|c|c|}
\hline \multicolumn{2}{|c|}{$\begin{array}{c}\text { Properties of toluene } \\
\text { (working fluid for the SLHPS) }\end{array}$} & \multicolumn{2}{|c|}{$\begin{array}{c}\text { Properties of } n \text {-hexane } \\
\text { (working fluid for the RORC) }\end{array}$} \\
\hline Parameter & Value & Parameter & Value \\
\hline Chemical formula & $\mathrm{C}_{7} \mathrm{H}_{8}$ & Chemical formula & $\mathrm{C}_{6} \mathrm{H}_{14}$ \\
\hline Molar mass (kg/kmol) & 92.14 & Molar mass (kg/kmol) & 86.18 \\
\hline Boiling temperature $\left({ }^{\circ} \mathrm{C}\right)$ & 111 & Boiling temperature $\left({ }^{\circ} \mathrm{C}\right)$ & 68.5 to 69.1 \\
\hline Density $\left(\mathrm{kg} / \mathrm{m}^{3}\right)$ & 867 & Density $\left(\mathrm{kg} / \mathrm{m}^{3}\right)$ & 655 \\
\hline Freezing temperature $\left({ }^{\circ} \mathrm{C}\right)$ & -95 & Freezing temperature $\left({ }^{\circ} \mathrm{C}\right)$ & -96 to -94 \\
\hline Critical temperature $\left({ }^{\circ} \mathrm{C}\right)$ & 318.6 & Critical temperature $\left({ }^{\circ} \mathrm{C}\right)$ & 234.7 \\
\hline Critical pressure $(\mathrm{MPa})$ & 4.126 & Critical pressure (MPa) & 3.058 \\
\hline
\end{tabular}

to produce domestic water. Since the working fluid has not reached the two phase states yet, at the outlet of the DWH, it is used to preheat the liquid before entering the RORC evaporator. The vapor is then condensed in the DWPH for warm water production. The working fluid is pumped into the regenerator and upon absorbing the heat, it streams to the RORC evaporator and the cycle is continuously repeated.

The SCCHP system comprises an SLHPE (including LHPs), a thermal sensor, vapor and liquid lines, vapor and liquid headers, compensation chamber, and RORC evaporator. In operation, the received solar energy transforms the toluene on the LHPs into saturated vapor, which streams along the LHPs to the vapor header mainly due to the buoyancy of vapor, auxiliary pump pressure, and gravity force created by the height difference between the RORC evaporator and SLHPE, as shown at Points 35 and 36 in Figure 1. The vapor is directed to the RORC evaporator through the vapor line. Then, through the liquid line, the toluene liquid enters the auxiliary pump. The auxiliary pump increases the pressure of the SLHPS working fluid and pumps it into the compensation chamber, which is placed under the vapor header. This amount of liquid is then divided and supplied to all of the LHP evaporators through a liquid feeder fixed at the upper part of the SLHPE, as shown in Figure 1. Furthermore, the liquid feeder pushes the liquid to descend into the LHP wicks equally. The schematic of LHP is shown in Figure 2.

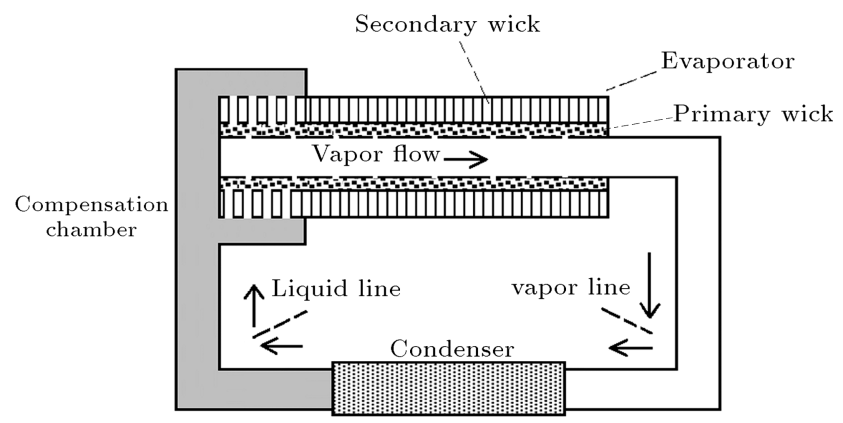

Figure 2. The schematic of Loop Heat Pipe (LHP).
Figure 3 shows the LHP as well as use of a threepath structure to supply rapid liquid distribution in the LHP wick.

Since the SRI varies with time, the SCCHP system in this study is supposed to work in three modes: solar mode (7:00 am to 9:00 am and 17:00 pm to 19:00 pm), solar and storage mode (9:00 am to 17:00 pm), and storage mode (19:00 pm to 7:00 am). Of note, $60 \%$ of the solar energy provided at the interval of 9:00 am to 17:00 pm is stored in the thermal storage tank. These modes are opted based on the average variations in the Solar Radiation Density (SRD) in the daytime in Tabriz, Iran. Figure 4 shows the average SRD variations in Tabriz, Iran and the three modes of operation for the SCCHP system, as well.

To conduct the thermodynamic analysis of the SCCHP, the following assumptions are taken into account:

- All the processes are considered to be operating in a steady state;

- Heat losses from piping and other components are neglected;

- There is an axisymmetric stream in all parts of the SLHPS;

- All of the SLHPS components are adiabatic except LHP evaporators;

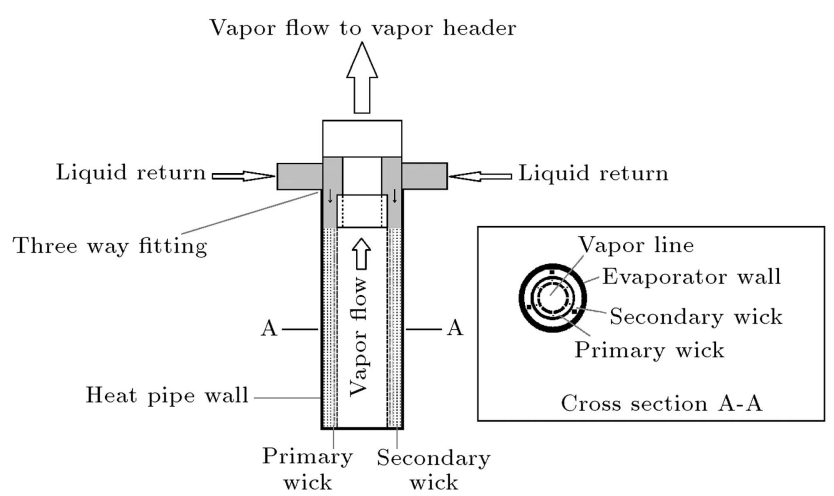

Figure 3. The schematic of three-way feeding and vapor/liquid separation structure. 


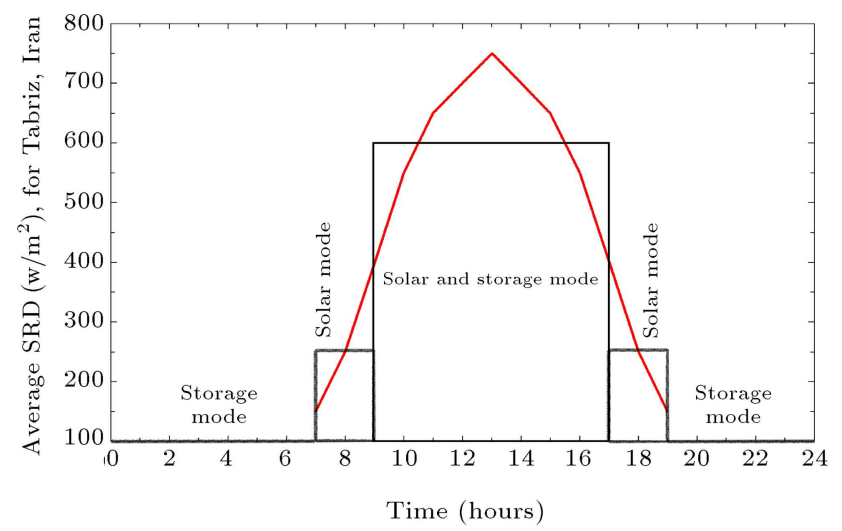

Figure 4. The average change of the Solar Radiation Density (SRD) in Tabriz, Iran, and three modes of operation for the Solar Combined Cooling, Heating, and Power (SCCHP) system.

- Pressure drops in the RORC cycle and absorption chiller are neglected;

- The dead states include $P_{0}=101 \mathrm{kPa}$ and $T_{0}=$ $298.15 \mathrm{~K}$;

- The ambient temperature is $T_{a m b}=301.15 \mathrm{~K}$;

- The average solar radiations from 7:00 to 9:00 and 17:00 to 19:00 was $250 \mathrm{~W} / \mathrm{m}^{2}$, and from 9:00 to 17:00 was $600 \mathrm{~W} / \mathrm{m}^{2}$;

- Chemical exergy of components and the potential kinetic energy and exergy were not taken into consideration.

\section{Analysis}

For thermodynamic modeling of the SCCHP, the developed equations were programmed using EES software. The input data used in this model are given in Tables 3 and 4 . The gravity effect pressure caused by the height difference between the RORC evaporator and SLHPE was $+14.936 \mathrm{kPa}$ (obtained using hydrostatic pressure equation), considered in the thermodynamic modeling of the SCCHP system.

In the forced circulation SLHPS, the system heat transfer capacity was controlled by five limits. According to Ref. [31], the heat transfer limits of the SLHPS are shown in Table 5.

The governing equations for the SCCHP are shown in Table 6. To model the SLHPS, the method used by Duffie and Beckman [32] was considered.

\section{Result and discussion}

In this section, the results of the thermodynamic modeling of the SCCHP system are presented.

\subsection{Validation of the solar evaporator model}

The SLHPE model was validated against the experimental study by Azad [33], as shown in Figure 5 . The proposed model is in good agreement with the experimental work.

\subsection{Validation of the CCHP cycle model}

Since no theoretical and experimental study has been conducted in the field of the SLHPE-based CCHP sys-

Table 3. Input data for the Solar Combined Cooling, Heating, and Power (SCCHP) system.

\begin{tabular}{|c|c|c|c|}
\hline Turbine efficiency & $85 \%$ & Working fluid & $n$-hexane \\
\hline Pumps efficiency & $85 \%$ & Evaporator pinch point temperature, $\left({ }^{\circ} \mathrm{C}\right)$ & 2 \\
\hline HPHEX pinch point temperature $\left({ }^{\circ} \mathrm{C}\right)$ & 2 & DWPH pinch point temperature, $\left({ }^{\circ} \mathrm{C}\right)$ & 2 \\
\hline DWPH pinch point temperature $\left({ }^{\circ} \mathrm{C}\right)$ & 4 & HPHEX type & Plate heat exchanger \\
\hline RORC pump inlet pressure $(\mathrm{kPa})$ & 20 & RORC evaporator type & Plate heat exchanger \\
\hline RORC turbine inlet pressure $(\mathrm{kPa})$ & 350 & DWPH type & Plate heat exchanger \\
\hline RORC turbine inlet temperature $\left({ }^{\circ} \mathrm{C}\right)$ & 119.7 & DWH type & Plate heat exchanger \\
\hline $\begin{array}{l}\text { Generator inlet temperature range, } \\
T_{11}\left({ }^{\circ} \mathrm{C}\right)\end{array}$ & $55-60$ & Cooling cycle working fluid & $\mathrm{LiBr}$ water \\
\hline $\begin{array}{l}\text { Chilled water inlet temperature, } \\
T_{17}\left({ }^{\circ} \mathrm{C}\right)\end{array}$ & 10 & $\begin{array}{l}\text { Cooling water inlet temperature, } \\
T_{13}\left({ }^{\circ} \mathrm{C}\right)\end{array}$ & 25 \\
\hline $\begin{array}{l}\text { Generator inlet mass flow rate, } \\
\dot{m}_{11}(\mathrm{~kg} / \mathrm{sec})\end{array}$ & 0.41 & $\begin{array}{l}\text { Cooling water mass flow rate, } \\
\dot{m}_{13}(\mathrm{~kg} / \mathrm{sec})\end{array}$ & 0.28 \\
\hline $\begin{array}{l}\text { Solution pump mass flow rate, } \\
\dot{m}_{1}(\mathrm{~kg} / \mathrm{sec})\end{array}$ & 0.05 & $\begin{array}{l}\text { Chilled water mass flow rate, } \\
\dot{m}_{17}(\mathrm{~kg} / \mathrm{sec})\end{array}$ & 0.4 \\
\hline $\begin{array}{l}\text { Cooling water mass flow rate to condenser, } \\
\dot{m}_{15}(\mathrm{~kg} / \mathrm{sec})\end{array}$ & 0.28 & $\begin{array}{l}\text { Effectiveness of the solution heat } \\
\text { exchanger }\end{array}$ & $70 \%$ \\
\hline $\begin{array}{l}\text { Overall heat transfer coefficient of the } \\
\text { absorber }(\mathrm{kW} / \mathrm{K})\end{array}$ & 1.8 & $\begin{array}{l}\text { Overall heat transfer coefficient of the } \\
\text { evaporator }(\mathrm{kW} / \mathrm{K})\end{array}$ & 2.25 \\
\hline $\begin{array}{l}\text { Overall heat transfer coefficient of the } \\
\text { condenser }(\mathrm{kW} / \mathrm{K})\end{array}$ & 1.2 & $\begin{array}{l}\text { Overall heat transfer coefficient of the } \\
\text { desorber }(\mathrm{kW} / \mathrm{K})\end{array}$ & 1 \\
\hline
\end{tabular}


Table 4. Input data for the Solar Loop Heat Pipe System (SLHPS).

\begin{tabular}{|c|c|c|c|}
\hline SLHPE length $(\mathrm{m})$ & 1.5 & LHPs evaporator length $(\mathrm{m})$ & 1.5 \\
\hline $\begin{array}{l}\text { Overall heat loss coefficient from the SLHPE } \\
\text { to ambient temperature }\left(\mathrm{kW} / \mathrm{m}^{2} . \mathrm{K}\right)\end{array}$ & 0.005 & SLHPE liquid filling mass $(\mathrm{kg})$ & 4.568 \\
\hline $\begin{array}{l}\text { Overall heat loss coefficient from the SLHPE } \\
\text { working fluid to ambient }\left(\mathrm{kW} / \mathrm{m}^{2} . \mathrm{K}\right)\end{array}$ & 0.0045 & $\begin{array}{l}\text { Critical radius of bubble generation } \\
\text { for toluene }(\mathrm{m})\end{array}$ & 0.00000007 \\
\hline SLHPE heat removal factor & 0.83 & LHPs material & Black Nickel \\
\hline SLHPE to HPHEX height difference & 1 & SLHPE optical efficiency & 0.8736 \\
\hline SLHPS heat exchanger height $(\mathrm{m})$ & 2 & SLHPS condensers length (m) & 2 \\
\hline SLHPS operating temperature range & $100-126\left({ }^{\circ} \mathrm{C}\right)$ & LHPs mesh ratio & $1: 1$ \\
\hline Hot storage tank temperature $\operatorname{drop}\left({ }^{\circ} \mathrm{C}\right)$ & 5 & $\begin{array}{l}\text { Cold storage tank temperature } \\
\text { drop }\left({ }^{\circ} \mathrm{C}\right)\end{array}$ & 3 \\
\hline $\begin{array}{l}\text { RORC evaporator operating pressure } \\
\text { range }(\mathrm{kPa})\end{array}$ & $0-4500$ & LHPs type & Mesh screen \\
\hline Number of LHP layers & Two layers & LHPs porosity & 0.64 \\
\hline STHEX pinch point temperature $\left({ }^{\circ} \mathrm{C}\right)$ & 2 & Internal diameter of the LHPs $(\mathrm{m})$ & 0.049 \\
\hline Thickness of the LHP wicks (m) & 0.0075 & Number of wick pores & 18 \\
\hline Thickness of the LHP secondary wicks (m) & 0.005 & SLHPS vapor header material & Black Nickel \\
\hline Thickness of the LHP primary wicks (m) & 0.0025 & $\begin{array}{l}\text { Effective diameter of the wick } \\
\text { pores }(\mathrm{m})\end{array}$ & 0.1111 \\
\hline External diameter of the LHP evaporators $(\mathrm{m})$ & 0.05 & SLHPS liquid line thickness (m) & 0.002 \\
\hline Internal diameter of the LHP vapor lines $(\mathrm{m})$ & 0.041 & SLHPS vapor line length $(\mathrm{m})$ & 3 \\
\hline RORC evaporator conductivity $\mathrm{W} / \mathrm{m} . \mathrm{K}$ & 16 & SLHPS vapor and liquid lines material & Cast iron \\
\hline $\begin{array}{l}\text { Thermal conductivity of the evaporator } \\
\text { wall }(\mathrm{W} / \mathrm{m} . \mathrm{K})\end{array}$ & 91 & SLHPS vapor line diameter $(\mathrm{m})$ & 0.6 \\
\hline $\begin{array}{l}\text { Thermal conductivity of evaporator } \\
\text { wick }(\mathrm{W} / \mathrm{m} . \mathrm{K})\end{array}$ & 91 & LHPs wall thickness (m) & 0.001 \\
\hline $\begin{array}{l}\text { RORC evaporator (SLHPS condenser) and } \\
\text { liquid line pressure drops }(\mathrm{kPa})\end{array}$ & 6 & SLHPS liquid line diameter $(\mathrm{m})$ & 0.5 \\
\hline $\begin{array}{l}\text { Solar evaporator and vapor line pressure } \\
\text { drops }(\mathrm{kPa})\end{array}$ & 11 & SLHPS liquid line length $(\mathrm{m})$ & 4 \\
\hline SLHPS average stream speed $(\mathrm{m} / \mathrm{sec})$ & 50 & SLHPS vapor line thickness (m) & 0.002 \\
\hline SLHPE transmission factor $(\tau)$ & 0.91 & SLHPE absorption factor $(\alpha)$ & 0.96 \\
\hline
\end{tabular}

Table 5. The operating limits of the Solar Loop Heat Pipe System (SLHPS).

\begin{tabular}{lccccc}
\hline \multicolumn{1}{c}{ Operating limits } & $\begin{array}{c}\text { Entrainment limit } \\
\dot{\boldsymbol{Q}}_{\boldsymbol{E} L}(\mathbf{k W})\end{array}$ & $\begin{array}{c}\text { Viscous limit } \\
\dot{\boldsymbol{Q}}_{\boldsymbol{V} L}(\mathbf{k W})\end{array}$ & $\begin{array}{c}\text { Sonic limit } \\
\dot{\boldsymbol{Q}}_{S L}(\mathbf{k W})\end{array}$ & $\begin{array}{c}\text { Boiling limit Filled liquid mass } \\
\dot{\boldsymbol{Q}}_{B L}(\mathbf{k W})\end{array}$ & $\begin{array}{l}\text { limit } \\
\dot{\boldsymbol{Q}}_{\boldsymbol{F} L}(\mathbf{k W})\end{array}$ \\
\hline Solar mode & 2594 & 51899 & 312451 & 1145000 & 1032 \\
Solar and storage mode & 2657 & 53151 & 319994 & 1172000 & 1032 \\
\hline
\end{tabular}

tems, the analysis of the SCCHP system was validated by the data provided by the Office of Energy Efficiency and Renewable Energy, Department of Energy, United States [34], as shown in Table 7, and the results were in good agreement.

\subsection{Validation of the absorption chiller model}

The analysis of the absorption chiller was validated by Herold et al. [35], as shown in Figure 6. According to this figure, considerable agreement between the current absorption chiller model and that of Herold et al. was observed.

\subsection{Energy and exergy analysis results}

The total numbers of the LHPs required by the SLHPE for the solar mode as well as the solar and storage mode were 6793 and 6957 , respectively. The results obtained from the energy analysis of the SCCHP system are summarized in Table 8. In addition, the results of the exergy analysis of the SCCHP system are summarized in Table 9, suggesting that for both solar and solar and 
Table 6. The governing equations for the Solar Combined Cooling, Heating, and Power (SCCHP) system.

SLHPS

Auxiliary pump (solar mode)

RORC evaporator (evaporator B)

Auxiliary pump (solar and storage mode)

STHEX

Hot storage tank

Hot storage tank valve

Cold storage tank

Cold storage tank valve

Storage pump

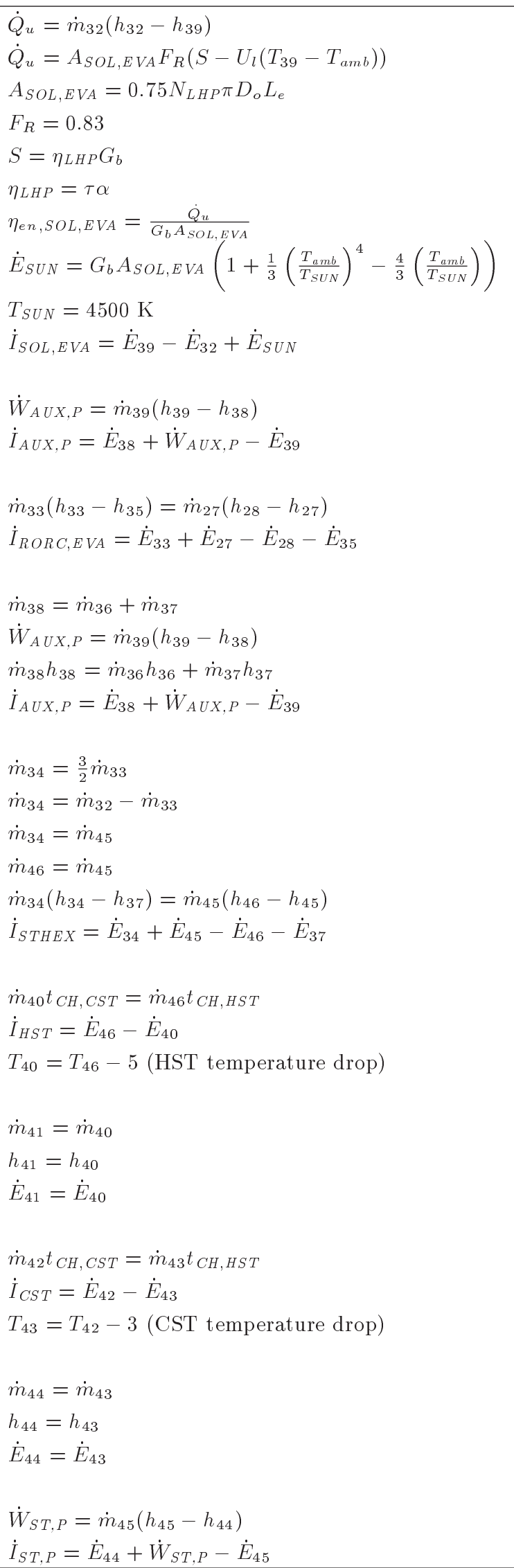


Table 6. The governing equations for the Solar Combined Cooling, Heating, and Power (SCCHP) system (continued).

RORC evaporator (evaporator A)

RORC turbine

Process heat exchanger

Regenerator

DWPH

DWH

RORC pump

Absorber

Solution pump

Solution heat exchanger

Desorber

Expansion valves $\dot{m}_{41}\left(h_{41}-h_{42}\right)=\dot{m}_{27}\left(h_{28}-h_{27}\right)$

$\dot{I}_{R O R C, E V A}=\dot{E}_{41}+\dot{E}_{27}-\dot{E}_{28}-\dot{E}_{42}$

$\dot{W}_{R O R C, T}=\dot{m}_{28}\left(h_{28}-h_{29}\right)$

$\dot{I}_{R O R C, T}=\dot{E}_{28}-\dot{E}_{29}-\dot{W}_{R O R C, T}$

$\dot{m}_{29}\left(h_{29}-h_{11}\right)=\dot{m}_{H P}\left(h_{31}-h_{30}\right)$

$\dot{I}_{H P}=\dot{E}_{29}+\dot{E}_{30}-\dot{E}_{11}-\dot{E}_{31}$

$\dot{m}_{19}\left(h_{19}-h_{22}\right)=\dot{m}_{26}\left(h_{27}-h_{26}\right)$

$\dot{I}_{R E G}=\dot{E}_{19}+\dot{E}_{26}-\dot{E}_{22}-\dot{E}_{27}$

$\dot{m}_{22}\left(h_{22}-h_{23}\right)=\dot{m}_{D W P H}\left(h_{25}-h_{24}\right)$

$\dot{I}_{D W P H}=\dot{E}_{22}+\dot{E}_{24}-\dot{E}_{23}-\dot{E}_{25}$

$\dot{m}_{12}\left(h_{12}-h_{19}\right)=\dot{m}_{D W H}\left(h_{21}-h_{20}\right)$

$\dot{I}_{D W H}=\dot{E}_{12}+\dot{E}_{20}-\dot{E}_{19}-\dot{E}_{21}$

$\dot{W}_{R O R C, P}=\dot{m}_{26}\left(h_{26}-h_{23}\right)$

$\dot{I}_{R O R C, P}=\dot{E}_{23}-\dot{E}_{26}+\dot{W}_{R O R C, P}$

$\dot{m}_{10}=\dot{m}_{6}+\dot{m}_{1}$

$\dot{m}_{1} x_{1}=\dot{m}_{6} x_{6}$

$\dot{m}_{10} h_{10}+\dot{m}_{6} h_{6}=\dot{m}_{1} h_{1}+\dot{Q}_{A B S}$

$\dot{I}_{A B S}=\dot{E}_{10}+\dot{E}_{6}+\dot{E}_{13}-\dot{E}_{1}-\dot{E}_{14}$

$\dot{W}_{S P}=\dot{m}_{2}\left(h_{2}-h_{1}\right)$

$\dot{I}_{S P}=\dot{E}_{1}-\dot{E}_{2}+\dot{W}_{S P}$

$\dot{m}_{2}=\dot{m}_{3}$

$\dot{m}_{4}=\dot{m}_{5}$

$x_{2}=x_{3}$

$x_{4}=x_{5}$

$\dot{m}_{2} h_{2}+\dot{m}_{4} h_{4}=\dot{m}_{3} h_{3}+\dot{m}_{5} h_{5}$

$\dot{I}_{S H E X}=\dot{E}_{2}+\dot{E}_{4}-\dot{E}_{3}-\dot{E}_{5}$

$\dot{m}_{3}=\dot{m}_{4}+\dot{m}_{7}$

$\dot{m}_{4} x_{4}=\dot{m}_{3} x_{3}$

$\dot{m}_{11}\left(h_{11}-h_{12}\right)+\dot{m}_{3} h_{3}=\dot{m}_{7} h_{7}+\dot{m}_{4} h_{4}$

$\dot{I_{G E N}}=\dot{E_{11}}+\dot{E}_{3}-\dot{E}_{4}-\dot{E}_{7}-\dot{E_{12}}$

$\dot{m}_{9}=\dot{m}_{8}$

$\dot{m}_{6}=\dot{m}_{5}$

$h_{9}=h_{8}$

$h_{6}=h_{5}$

$\dot{I}_{E X V}=\dot{E}_{8}+\dot{E}_{5}-\dot{E}_{9}-\dot{E}_{6}$ 
Table 6. The governing equations for the Solar Combined Cooling, Heating, and Power (SCCHP) system (continued).

$\begin{array}{ll} & \dot{m}_{8}=\dot{m}_{7} \\ & \dot{m}_{7} h_{7}=\dot{m}_{8} h_{8}+\dot{Q}_{C o n d} \\ & \dot{I}_{C o n d}=\dot{E}_{7}+\dot{E}_{15}-\dot{E}_{8}-\dot{E}_{16} \\ & \dot{m}_{9}=\dot{m}_{10} \\ & \dot{Q}_{E V P}=\dot{m}_{10} h_{10}-\dot{m}_{9} h_{9} \\ & \dot{I}_{E V P}=\dot{E}_{17}+\dot{E}_{9}-\dot{E}_{18}-\dot{E}_{10} \\ \text { Evaporator } & \\ \text { The log mean temperature } & \dot{Q}=U A \cdot L M T D \\ \text { difference method formulas } & L M T D=\frac{\left(T_{h, \text { in }}-T_{c, \text { out }}\right)-\left(T_{h, \text { out }}-T_{c, \text { in }}\right)}{\ln \left[\frac{T_{h, \text { in }}-T_{c, o u t}}{\left.T_{h, \text { out }}-T_{c, \text { in }}\right]}\right.}\end{array}$

The energy efficiency of the SCCHP system for the solar mode

$$
\eta_{e n}=\frac{\dot{Q}_{H P}+\dot{Q}_{D W H}+\dot{Q}_{D W P H}+\dot{Q}_{E V P}+\dot{W}_{N e t, T}}{G_{b} A_{S O L, E V A}}
$$

The exergy efficiency of the SCCHP system for the solar mode

$$
\eta_{e x}=\frac{\dot{W}_{N e t, T}+\dot{E}_{D W P H, o u t}-\dot{E}_{D W P H, \text { in }}+\dot{E}_{D W H, \text { out }}-\dot{E}_{D W H, \text { in }}+\dot{E}_{H P, \text { out }}-\dot{E}_{H P, \text { in }}+\dot{E}_{18}-\dot{E}_{17}}{\dot{E}_{S U N}}
$$

The energy efficiency of the SCCHP system for the $\eta_{e n}=\frac{\dot{Q}_{S T, H E X}+\dot{Q}_{H P}+\dot{Q}_{D W H}+\dot{Q}_{D W P H}+\dot{Q}_{E V P}+\dot{W}_{N e t, T}}{G_{b} A_{S O L, E V A}}$ solar and storage mode

The exergy efficiency of the SCCHP system for the $\eta_{e x}=\frac{\dot{W}_{N e t, T}+\dot{E}_{D W P H, \text { out }}-\dot{E}_{D W P H, \text { in }}+\dot{E}_{D W H, \text { out }}-\dot{E}_{D W H, \text { in }}+\dot{E}_{H P, \text { out }}-\dot{E}_{H P, \text { in }}+\dot{E}_{18}-\dot{E}_{17}+\dot{E}_{46}-\dot{E}_{45}}{\dot{E}_{S U N}}$ solar and storage mode

The energy efficiency of the SCCHP system for the storage mode

$$
\eta_{e n}=\frac{\dot{Q}_{H P}+\dot{Q}_{D W H}+\dot{Q}_{D W P H}+\dot{Q}_{E V P}+\dot{W}_{N e t, T}}{\dot{m}_{34}\left(h_{34}-h_{37}\right)}
$$

The exergy efficiency of the SCCHP system for the

$$
\eta_{e x}=\frac{\dot{W}_{N e t, T}+\dot{E}_{D W P H, \text { out }}-\dot{E}_{D W P H, \text { in }}+\dot{E}_{D W H, o u t}-\dot{E}_{D W H, \text { in }}+\dot{E}_{H P, \text { out }}-\dot{E}_{H P, \text { in }}+\dot{E}_{18}-\dot{E}_{17}}{\dot{E}_{34}-\dot{E}_{37}}
$$
storage mode

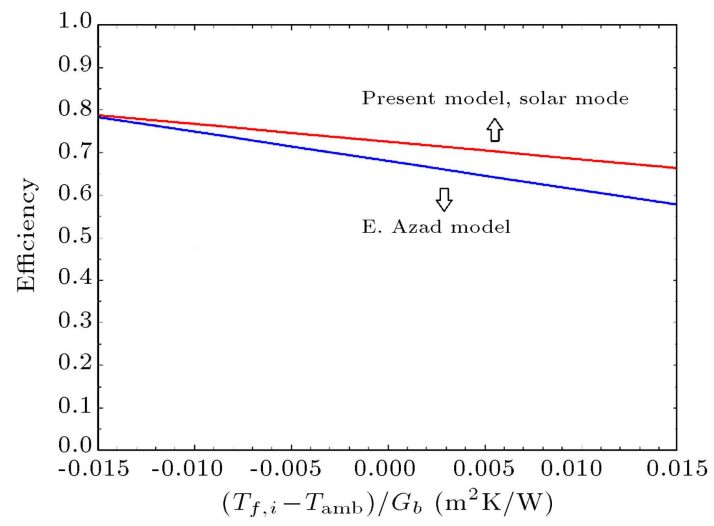

(a)

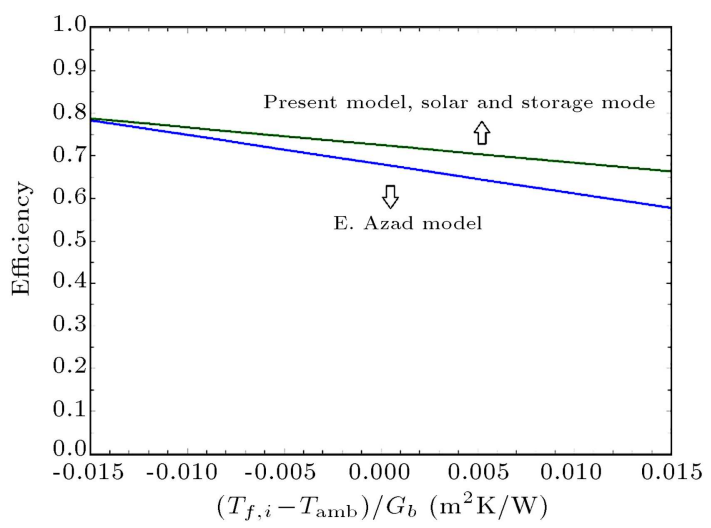

(b)

Figure 5. Validation of the Solar Loop Heat Pipe Evaportor (SLHPE) model in comparison with Azad's model [33]: (a) solar mode and (b) solar and storage mode. 
Table 7. Validation of the Solar Combined Cooling, Heating, and Power (SCCHP) cycle model.

\begin{tabular}{ccc}
\hline $\begin{array}{c}\text { Data from United States } \\
\text { Department of Energy }\end{array}$ & $\begin{array}{c}\text { Present study } \\
\text { (solar mode) }\end{array}$ & $\begin{array}{c}\text { Present study } \\
\text { (solar and storage mode) }\end{array}$ \\
\hline Reasonable efficiency of overall CCHP cycle: & Overall CCHP cycle efficiency: & Overall CCHP cycle efficiency: \\
$65-75 \%$ & $70.52 \%$ & $72.09 \%$ \\
\hline
\end{tabular}

Table 8. The results of the energy analysis of the Solar Combined Cooling, Heating, and Power (SCCHP) system.

\begin{tabular}{lccc}
\hline \multicolumn{1}{c}{ Parameter } & Solar mode & Solar and storage mode & Storage mode \\
\hline SLHPE useful energy & $212.7 \mathrm{~kW}$ & $532.9 \mathrm{~kW}$ & - \\
HPHEX energy flow & $8.108 \mathrm{~kW}$ & $8.108 \mathrm{~kW}$ & $4.438 \mathrm{~kW}$ \\
DWH energy flow & $19.04 \mathrm{~kW}$ & $19.04 \mathrm{~kW}$ & $19.04 \mathrm{~kW}$ \\
DWPH energy flow & $148.3 \mathrm{~kW}$ & $148.3 \mathrm{~kW}$ & $148.3 \mathrm{~kW}$ \\
Regenerator energy flow & $2.062 \mathrm{~kW}$ & $2.062 \mathrm{~kW}$ & $2.062 \mathrm{~kW}$ \\
RORC evaporator energy flow & $212.7 \mathrm{~kW}$ & $212.7 \mathrm{~kW}$ & $208.6 \mathrm{~kW}$ \\
RORC turbine net power & $33.2 \mathrm{~kW}$ & $33.19 \mathrm{~kW}$ & $32.58 \mathrm{~kW}$ \\
RORC pump input power & $0.2414 \mathrm{~kW}$ & $0.2414 \mathrm{~kW}$ & $0.2414 \mathrm{~kW}$ \\
Auxiliary pump input power & $0.001131 \mathrm{~kW}$ & $0.008945 \mathrm{~kW}$ & - \\
Desorber energy flow & $4.134 \mathrm{~kW}$ & $4.134 \mathrm{~kW}$ & $4.134 \mathrm{~kW}$ \\
Condenser energy flow & $3.111 \mathrm{~kW}$ & $3.111 \mathrm{~kW}$ & $3.111 \mathrm{~kW}$ \\
Evaporator energy flow & $3.008 \mathrm{~kW}$ & $3.008 \mathrm{~kW}$ & $3.008 \mathrm{~kW}$ \\
Absorber energy flow & $4.031 \mathrm{~kW}$ & $4.031 \mathrm{~kW}$ & $4.031 \mathrm{~kW}$ \\
Solution pump input power & $0.00009977 \mathrm{~kW}$ & $0.00009977 \mathrm{~kW}$ & $0.00009977 \mathrm{~kW}$ \\
STHEX energy flow & - & $320.1 \mathrm{~kW}$ & $320.1 \mathrm{~kW}$ \\
Storage pump input power & - & - & $0.09917 \mathrm{~kW}$ \\
SCCHP cycle efficiency & $70.52 \%$ & $72.09 \%$ & $64.77 \%$ \\
\hline
\end{tabular}

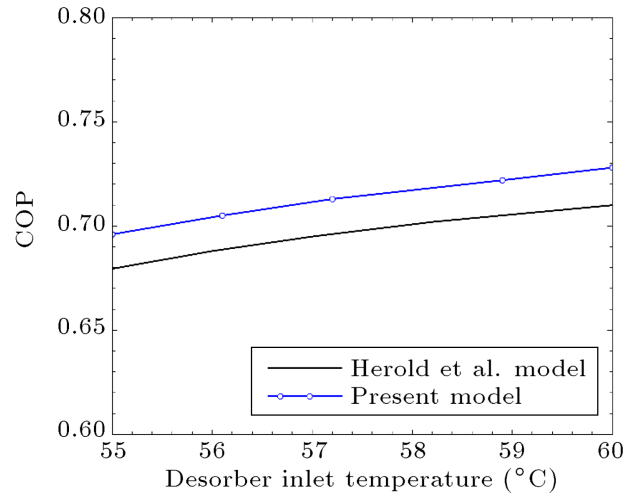

(a)

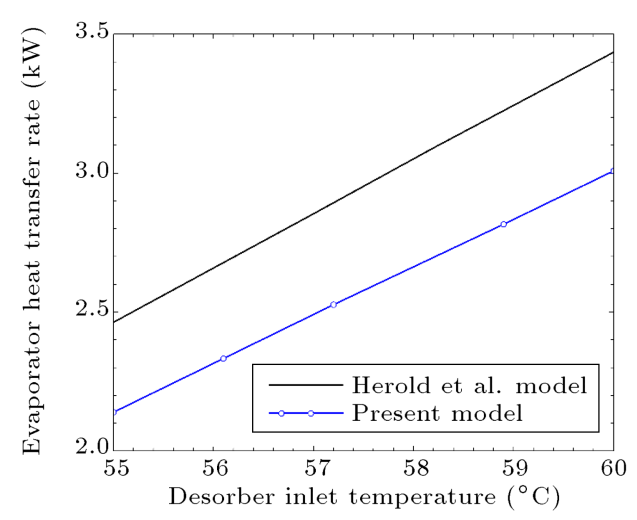

(b)

Figure 6. Validation of the absorption chiller model against the model proposed by Herold et al., Coefficient of Performance (COP), and evaporator heat rate versus generator inlet temperature.

storage modes, the main source of exergy destruction is the SLHPE, while for the storage mode, the main source of exergy destruction is the hot storage tank.

\subsection{The effect of variations of the RORC evaporator pinch point temperature on the SCCHP cycle performance}

Figure 7 shows the RORC evaporator pinch point temperature variations with the energy and exergy efficiencies, SCCHP cycle exergy destruction rate, heat flow of the RORC evaporator, and turbine work for the three operation modes. As the pinch point temperature increased, the heat absorbed by the RORC evaporator decreased and the utilization of this energy decreased. Therefore, the enthalpy of the $n$-hexane vapor in the RORC evaporator decreased which reduced the RORC evaporator heat flow and increased the overall cycle exergy destruction rate, leading to a decrease in the energy and exergy efficiency of the proposed system for all three operating modes. 

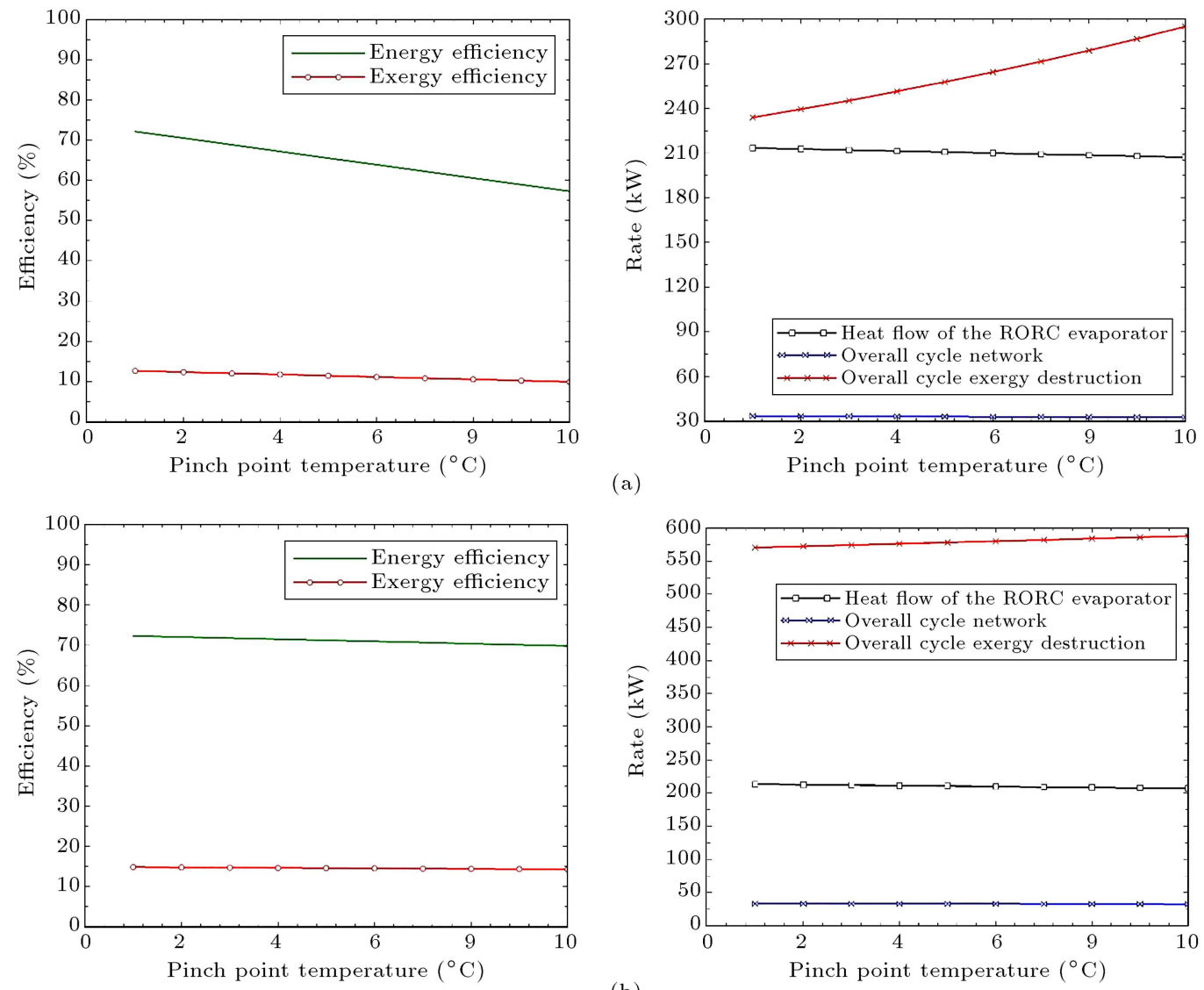

(a)
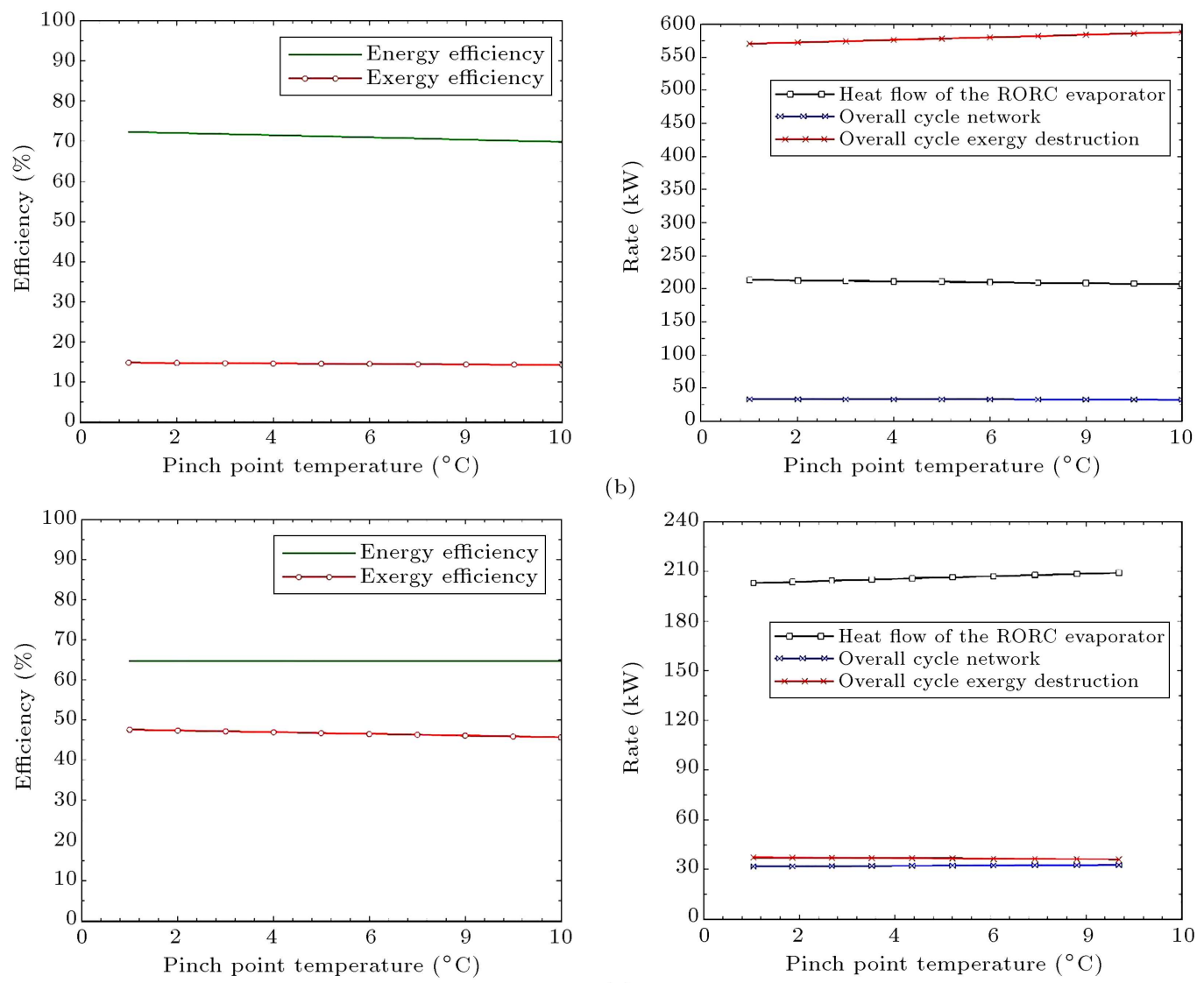

(c)

Figure 7. Variation in the Regenerative Organic Rankine Cycle (RORC) evaporator pinch point temperature with the energy efficiency, exergy efficiency, overall cycle exergy destruction rate, heat flow of the RORC evaporator, and the turbine work: (a) Solar mode, (b) solar and storage mode, and (c) storage mode.

\subsection{The effect of varying ambient temperature on the SCCHP cycle performance}

Figure 8 shows the variation of energy and exergy efficiencies as well as the SLHPE exergy destruction rate with ambient temperature in both solar and solar and storage modes. As observed earlier, increasing the ambient temperature would increase the energy and exergy efficiencies of the SCCHP system, decrease the SLHPE exergy destruction rate, mainly because the SLHPS was designed to produce toluene saturated vapor, decrease the SLHPE heat losses and the total number of the LHPs, and finally reduce the SLHPE exergy destruction rate for the solar and the solar and storage modes.

\subsection{The effect of variations in the SRI on the SCCHP cycle performance}

Figure 9 shows the variations in energy and exergy efficiencies and solar evaporator exergy destruction rate with SRI for both solar and the solar and storage 
Table 9. The results of the exergy analysis of the Solar Combined Cooling, Heating, and Power (SCCHP) system.

\begin{tabular}{|c|c|c|c|}
\hline Parameter & Solar mode & Solar and storage mode & Storage mode \\
\hline SLHPE exergy destruction rate & $227.4 \mathrm{~kW}$ & $557 \mathrm{~kW}$ & - \\
\hline RORC evaporator exergy destruction rate & $5.336 \mathrm{~kW}$ & $5.336 \mathrm{~kW}$ & $3.228 \mathrm{~kW}$ \\
\hline RORC turbine exergy destruction rate & $5.175 \mathrm{~kW}$ & $5.175 \mathrm{~kW}$ & $5.168 \mathrm{~kW}$ \\
\hline DWPH exergy destruction rate & $1.258 \mathrm{~kW}$ & $1.258 \mathrm{~kW}$ & $1.258 \mathrm{~kW}$ \\
\hline DWH exergy destruction rate & $1.293 \mathrm{~kW}$ & $0.09601 \mathrm{~kW}$ & $0.09601 \mathrm{~kW}$ \\
\hline STHEX exergy destruction rate & - & $3.351 \mathrm{~kW}$ & $3.351 \mathrm{~kW}$ \\
\hline Hot storage tank exergy destruction rate & - & - & $22.77 \mathrm{~kW}$ \\
\hline Cold storage tank exergy destruction rate & - & - & $0.03913 \mathrm{~kW}$ \\
\hline Other components exergy destruction rate & $1.465 \mathrm{~kW}$ & $1.43079 \mathrm{~kW}$ & $1.5048 \mathrm{~kW}$ \\
\hline SCCHP cycle efficiency & $12.36 \%$ & $14.78 \%$ & $47.45 \%$ \\
\hline
\end{tabular}
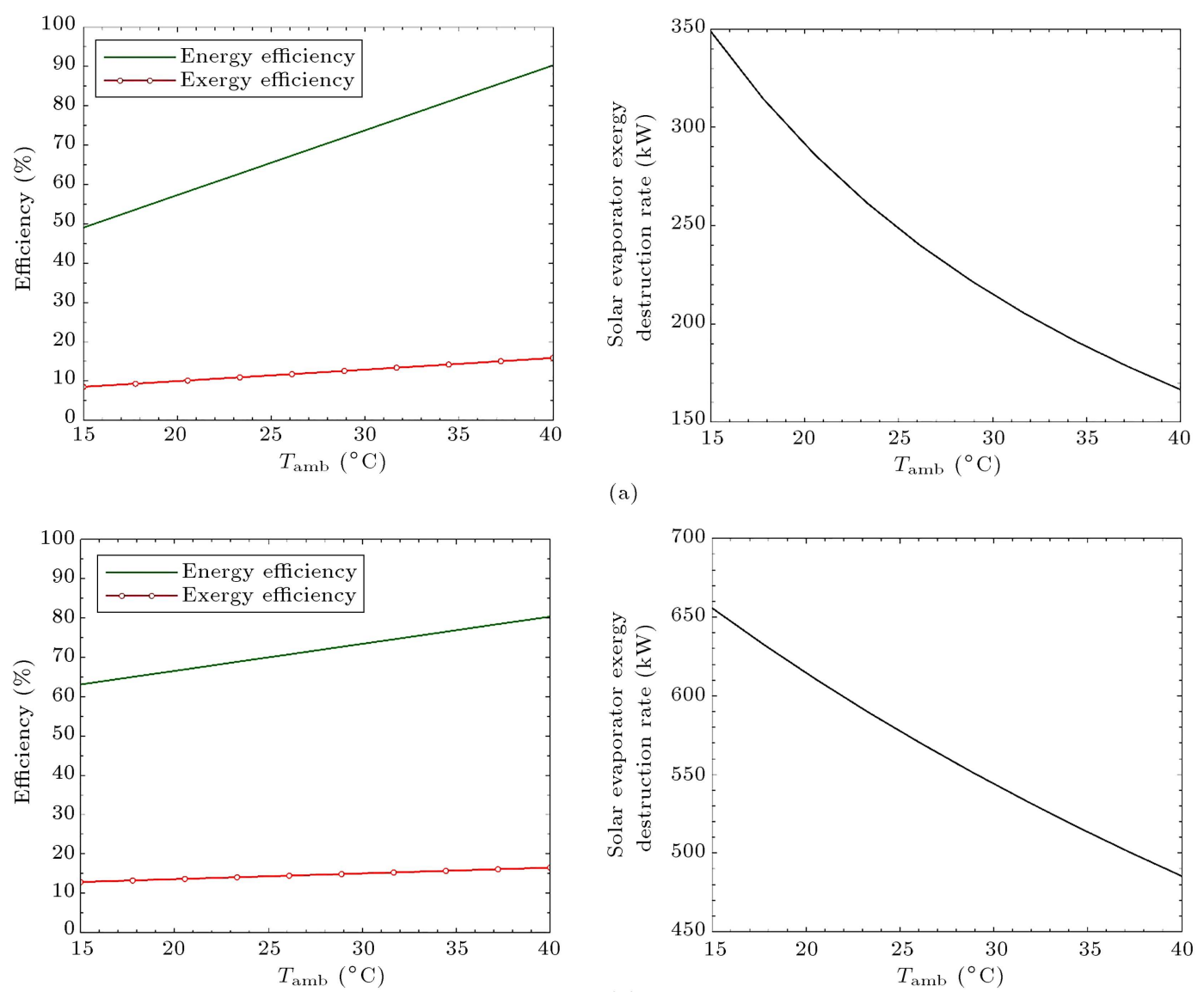

(a)

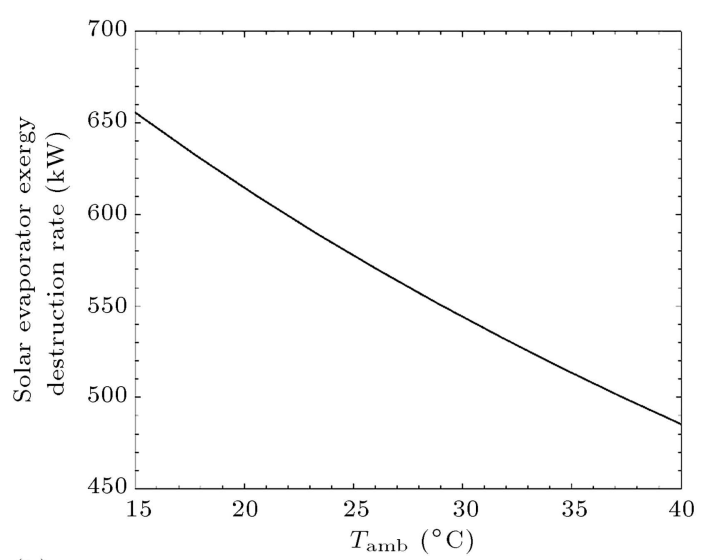

(b)

Figure 8. Variation in the ambient temperature with the energy efficiency, exergy efficiency, and solar evaporator exergy destruction rate for (a) solar mode and (b) solar and storage mode.

modes. As observed earlier, increasing the SRI would increase the energy and exergy efficiencies of the proposed system due to an increase in the SRI, and decrease the solar evaporator heat losses and exergy destruction rate for the solar and the solar and storage operation modes. These results were obtained because the SLHPS was designed to produce toluene saturated vapor; furthermore, increasing the SRI would reduce the SLHPE heat losses and the total number of the LHPs, decrease the SLHPE exergy destruction rate for both solar and the solar and storage modes, and improve the SCCHP cycle performance. 

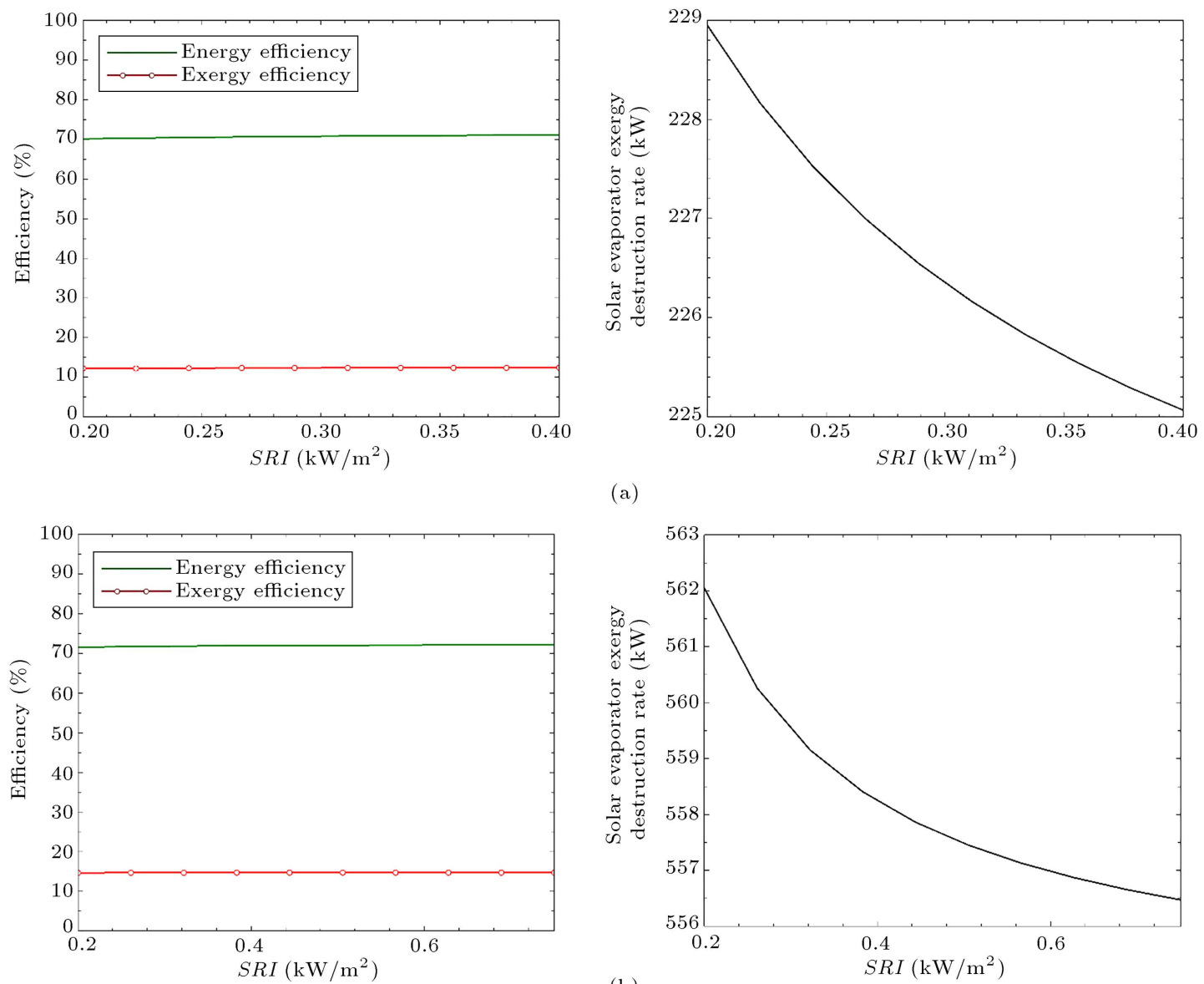

(a)

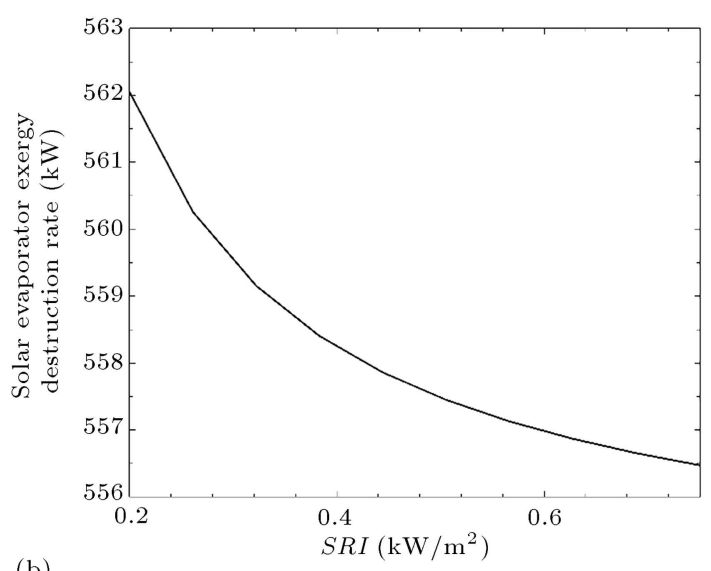

Figure 9. Variation in Solar Radiation Intensity (SRI) of the energy efficiency, exergy efficiency, and solar evaporator exergy destruction rate for (a) solar mode and (b) solar and storage mode.

\subsection{The effect of variations in the turbine inlet pressure on the $S C C H P$ cycle performance}

Figure 10 shows the variations in energy and exergy efficiencies, turbine work rate, and overall cycle exergy destruction rate with turbine inlet pressure in all of the three operation modes. As observed earlier, with an increase in the turbine inlet pressure, the energy efficiency decreased and the turbine work rate increased. Moreover, such an increase in turbine inlet pressure led to a decrease in turbine extraction temperature; besides, since this temperature was the primary flow temperature for the HPHEX, a reduction in the primary enthalpy of the HPHEX, energy flow of the HPHEX, and heating load of the HPHEX was observed. Figure 10 shows that an increase in the turbine inlet pressure would enhance the exergy efficiency of the SCCHP system. As the turbine inlet pressure increased, the enthalpy drops across the turbine increased, the overall irreversibility of the SCCHP system decreased, and the net power output of the system increased. Moreover, small temperature differences between the fluid streams improved the exergy efficiency of the system in all of the three operation modes.

\section{Conclusions}

In this study, the steady state thermodynamic analysis of the Solar Combined Cooling, Heating, and Power (SCCHP) system in all of the three operation modes was conducted. The present study aimed to find, expand, and model a new loop-heat-pipe-based SCCHP system and introduce a sustainable and renewable novel solar system. The results showed that while the main source of the exergy destruction for both solar and the solar and storage modes was the SLHPE, it was the hot storage tank for the storage mode. The energy efficiency of the proposed system was $70.52 \%$ for the solar mode, $72.09 \%$ for the solar and storage mode, and $64.77 \%$ for the storage mode. In addition, the exergy efficiency of the proposed system was $12.36 \%$ for the solar mode, $14.78 \%$ for the solar and storage mode, and $47.45 \%$ for the storage mode. Loop Heat Pipes (LHPs) could significantly contribute to the development of solar thermal systems due to their potential for low- 

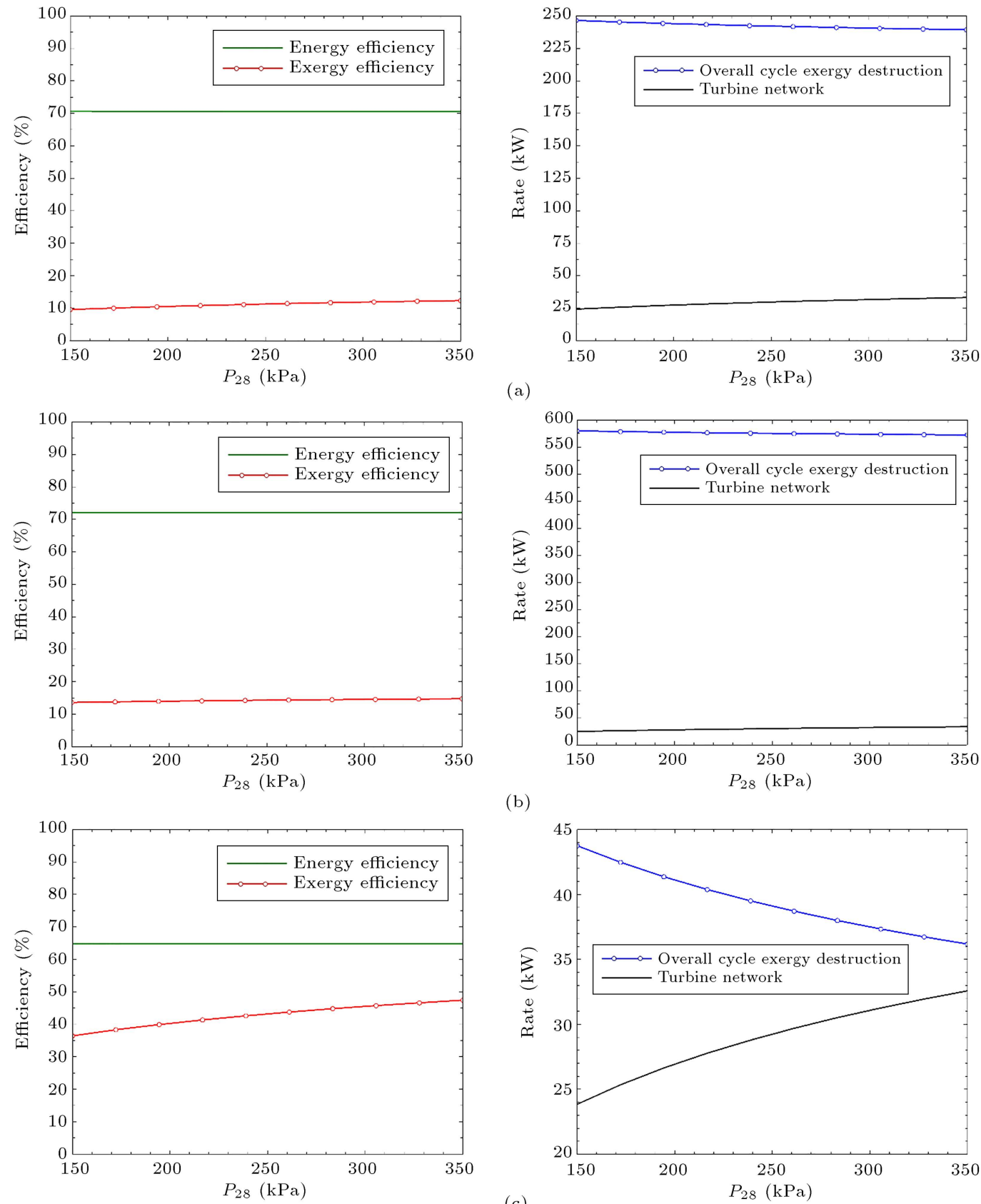

(b)

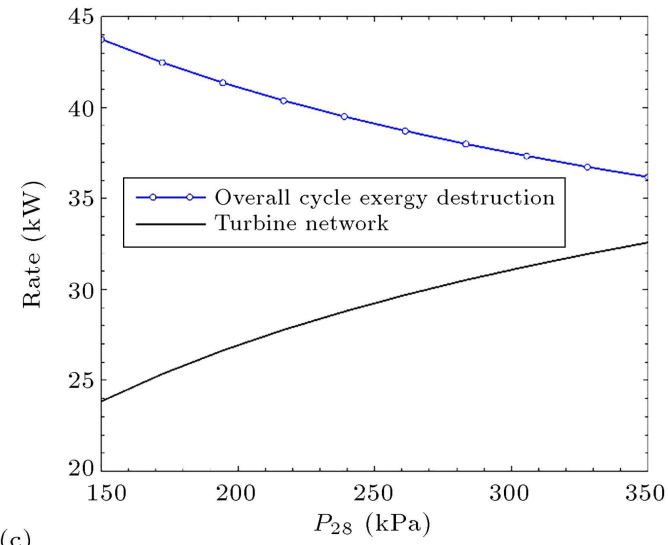

Figure 10. Variation in the turbine inlet pressure with the energy efficiency, exergy efficiency, turbine work rate, and overall cycle exergy destruction rate for (a) solar mode, (b) solar and storage mode, and (c) storage mode.

thermal resistance, high-thermal capacity, and simple structure. The results of this research facilitate a better understanding of the performance of SLHPEs and create new layouts associated with designing the LHP-based solar thermal systems.

\section{Acknowledgements}

The authors are thankful for the Management and Staff of National Iranian Oil Refining and Distribution Company for their technical support.

\section{Nomenclature}

\begin{tabular}{|c|c|}
\hline$A$ & Area $\left(\mathrm{m}^{2}\right)$ \\
\hline$c v$ & Control volume \\
\hline $\mathrm{CHP}$ & Combined Heating and Power \\
\hline CCHP & $\begin{array}{l}\text { Combined Cooling, Heating, and } \\
\text { Power }\end{array}$ \\
\hline CSP & Concentrated Solar Power \\
\hline $\mathrm{COP}$ & Coefficient Of Performance \\
\hline$D$ & Vapor line diameter \\
\hline
\end{tabular}




\begin{tabular}{|c|c|c|c|}
\hline DWH & Domestic Water Heater & $T_{\mathrm{SUN}}$ & Sun temperature $(\mathrm{K})$ \\
\hline DWPH & Domestic Water Preheater & $t$ & Time \\
\hline$E$ & Energy & $U_{l}$ & Overall heat loss coefficient from \\
\hline$e$ & Exit & & SLHPE to ambient, $\left(\mathrm{kW} / \mathrm{m}^{2} . \mathrm{K}\right)$ \\
\hline$\dot{E}$ & Exergy rate $(\mathrm{kW})$ & $U$ & Heat transfer coefficient $\left(\mathrm{kW} / \mathrm{m}^{2} . \mathrm{K}\right)$ \\
\hline$\dot{E}_{\mathrm{SUN}}$ & $\begin{array}{l}\text { The total inlet exergy to the cycle } \\
(\mathrm{kW})\end{array}$ & $U A$ & $\begin{array}{l}\text { Overall heat transfer coefficient } \\
(\mathrm{kW} / \mathrm{K})\end{array}$ \\
\hline$F_{R}$ & SLHPE heat removal factor & $\dot{W}_{N e t, T}$ & Turbine work rate $(\mathrm{kW})$ \\
\hline$G_{b}$ & Solar radiation $\left(\mathrm{W} / \mathrm{m}^{2}\right)$ & $\dot{W}$ & Work rate $(\mathrm{kW})$ \\
\hline$h$ & Specific enthalpy (kj/kg) & $\mathrm{W}$ & Watts \\
\hline HPHEX & Heating Process Heat Exchanger & $x$ & LiBr mass concentration \\
\hline$i$ & Inlet & \multicolumn{2}{|c|}{ Greek symbols } \\
\hline$\dot{I}$ & Exergy destruction rate $(\mathrm{kW})$ & & \\
\hline $\mathrm{K}$ & Kelvin & $\alpha$ & The SLHPE absorption factor \\
\hline $\mathrm{kWh}$ & Kilowatt hour & $\delta$ & Thickness \\
\hline $\mathrm{kg}$ & Kilograms & $\eta$ & Efficiency \\
\hline$L$ & Length & $\eta_{L H P}$ & LHP optical efficiency \\
\hline LMTD & Log Mean Temperature Difference & $\tau$ & SLHPE transmission factor \\
\hline & $\left({ }^{\circ} \mathrm{C}\right)$ & $\psi$ & Specific exergy (kJ/kg) \\
\hline$L_{e}$ & Solar evaporator length & \multicolumn{2}{|l|}{ Subscripts } \\
\hline LHP & Loop Heat Pipe & $A U X, P$ & Auxiliary Pump \\
\hline$m_{f}$ & $\begin{array}{l}\text { Solar evaporator liquid filling mass } \\
(\mathrm{kg})\end{array}$ & $A B S$ & Absorber \\
\hline$\dot{m}$ & Mass flow rate $(\mathrm{kg} / \mathrm{sec})$ & $a m b$ & Ambient \\
\hline$m$ & Mass now rate & $B L$ & Boiling Limit \\
\hline $\mathrm{m}$ & Mass or meter & Cond & Condenser \\
\hline$N_{P}$ & Number of wick pores & $C S T$ & Cold Storage Tank \\
\hline$N_{L H P}$ & Number of LHPs & $C H, H S T$ & Charging time of the Hot Storage Tank \\
\hline out & Exit & $C H, C S T$ & Charging time of the Cold Storage \\
\hline$P$ & Pressure (kPa) & & Tank \\
\hline $\mathrm{Pa}$ & Pascal & $D W H$ & Domestic Water Heater \\
\hline PV & Photovoltaic & $D W P H$ & Domestic water preheater \\
\hline PVT & Photovoltaic Thermal & $E X V$ & Expansion Valve \\
\hline $\mathrm{PCM}$ & Phase Change Material & $E V P$ & Evaporator \\
\hline$\dot{Q}$ & Heat rate $(\mathrm{kW})$ & $E L$ & Entrainment Limit \\
\hline RORC & Regenerative Organic Rankine Cycle & $e x$ & Exergy efficiency \\
\hline $\mathrm{SRD}$ & Solar Radiation Density & en & Energy efficiency \\
\hline SOL, EVA & Solar loop heat pipe evaporator & $F L$ & Filled Liquid mass limit \\
\hline$s$ & Specific entropy (kj/kg.K) & $f, i$ & Fluid entering solar evaporator \\
\hline $\sec$ & Second & $G E N$ & Generator (desorber) \\
\hline SLHPS & Solar Loop Heat Pipe System & Heat & Exergy transfer by heat $(\mathrm{kW})$ \\
\hline$S$ & Radiation absorbed by the SLHPE & $H P$ & Heating Process \\
\hline SRI & Solar Radiation Intensity & $H S T$ & Hot Storage Tank \\
\hline STHEX & Storage Heat Exchanger & in & Inlet \\
\hline SCCHP & Solar CCHP & $O$ & Outer \\
\hline SLHPE & Solar Loop Heat Pipe Evaporator & out & Outlet \\
\hline$T$ & Temperature & $p w$ & LHPs primary wick \\
\hline
\end{tabular}




$\begin{array}{ll}R O R C, T & \text { RORC Turbine } \\ R O R C, P & \text { RORC Pump } \\ R O R C, E V A & \text { RORC Evaporator } \\ R E G & \text { Regenerator } \\ S L & \text { Sonic Limit } \\ S P & \text { Solution Pump } \\ S U N & \text { Sun } \\ S H E X & \text { Solution heat exchanger } \\ s w & \text { LHP secondary wick } \\ S O L, E V A & \text { Solar loop heat pipe evaporator } \\ S T, P & \text { Storage Pump } \\ u & \text { Useful } \\ v h & \text { Vapor header } \\ V L & \text { Viscous Limit } \\ w & \text { LHP wicks }\end{array}$

\section{References}

1. Villarini, M., Tascioni, R., Arteconi, A., and Cioccolanti, L. "Influence of the incident radiation on the energy performance of two small-scale solar organic Rankine cycle trigenerative systems: A simulation analysis", Applied Energy, 242, pp. 1176-1188 (2019).

2. Dabwan, Y.N., Pei, G., Gao, G., Li, J., and Feng, J. "Performance analysis of integrated linear fresnel reflector with a conventional cooling, heat, and power tri-generation plant", Renewable Energy, 138, pp. 639-650 (2019).

3. Bellos, E. and Tzivanidis, C. "Evaluation of a solar driven trigeneration system with conventional and new criteria", International Journal of Sustainable Energy, 38(3), pp. 238-252 (2019).

4. Bellos, E. and Tzivanidis, C. "Parametric analysis and optimization of a solar driven trigeneration system based on ORC and absorption heat pump", Journal of Cleaner Production, 161, pp. 493-509 (2017).

5. Su, B., Han, W., and Jin, H. "Proposal and assessment of a novel integrated CCHP system with biogas steam reforming using solar energy", Applied Energy, 206, pp. 1-11 (2017).

6. Corumlu, V., Ozsoy, A., and Ozturk, M. "Thermodynamic studies of a novel heat pipe evacuated tube solar collectors based integrated process for hydrogen production", International Journal of Hydrogen Energy, 43(2), pp. 1060-1070 (2018).

7. Khan, J. and Arsalan, M.H. "Solar power technologies for sustainable electricity generation-A review", Renewable and Sustainable Energy Reviews, 55, pp. 414-425 (2016).

8. Sampaio, P.G.V. and González, M.O.A. "Photovoltaic solar energy: Conceptual framework", Renewable and Sustainable Energy Reviews, 74, pp. 590-601 (2017).
9. Maydanik, Y., Pastukhov, V., and Chernysheva, M. "Development and investigation of a loop heat pipe with a high heat-transfer capacity", Applied Thermal Engineering, 130, pp. 1052-1061 (2018).

10. Yunus, A.C., Heat Transfer a Practical Approach, McGraw-Hill (2003).

11. Shafieian, A., Khiadani, M., and Nosrati, A. "Strategies to improve the thermal performance of heat pipe solar collectors in solar systems: A review", Energy Conversion and Management, 183, pp. 307331 (2019).

12. Shafieian, A., Khiadani, M., and Nosrati, A. "Thermal performance of an evacuated tube heat pipe solar water heating system in cold season", Applied Thermal Engineering, 149, pp. 644-657 (2019).

13. Allouhi, A., Amine, M.B., Buker, M.S., Kousksou, T., and Jamil, A. "Forced-circulation solar water heating system using heat pipe-flat plate collectors: Energy and exergy analysis", Energy, 180, pp. 429-443 (2019).

14. Li, H. and Sun, Y. "Performance optimization and benefit analyses of a photovoltaic loop heat pipe/solar assisted heat pump water heating system", Renewable Energy, 134, pp. 1240-1247 (2019).

15. Diallo, T.M., Yu, M., Zhou, J., Zhao, X., Shittu, S., Li, G., Ji, J., and Hardy, D. "Energy performance analysis of a novel solar PVT loop heat pipe employing a microchannel heat pipe evaporator and a PCM triple heat exchanger", Energy, 167, pp. 866-888 (2019).

16. Lu, Y. and Wang, J. "Thermodynamics performance analysis of solar-assisted combined cooling, heating and power system with thermal storage", Energy Procedia, 142, pp. 3226-3233 (2017).

17. Hands, S., Sethuvenkatraman, S., Peristy, M., Rowe, D., and White, S. "Performance analysis \& energy benefits of a desiccant based solar assisted trigeneration system in a building", Renewable Energy, 85, pp. 865879 (2016).

18. Wang, J., Lu, Y., Yang, Y., and Mao, T. "Thermodynamic performance analysis and optimization of a solar-assisted combined cooling, heating and power system", Energy, 115, pp. 49-59 (2016).

19. Yuksel, Y.E., Ozturk, M., and Dincer, I. "Thermodynamic performance assessment of a novel environmentally-benign solar energy based integrated system", Energy Conversion and Management, 119, pp. 109-120 (2016).

20. Azad, E. "Experimental analysis of thermal performance of solar collectors with different numbers of heat pipes versus a flow-through solar collector", Renewable and Sustainable Energy Reviews, 82, pp. 4320-4325 (2018).

21. Li, H. and Sun, Y. "Operational performance study on a photovoltaic loop heat pipe/solar assisted heat pump water heating system", Energy and Buildings, 158, pp. 861-872 (2018). 
22. Jouhara, H., Chauhan, A., Nannou, T., Almahmoud, S., Delpech, B., and Wrobel, L.C. "Heat pipe based systems-Advances and applications", Energy, 128, pp. 729-754 (2017).

23. Jouhara, H., Szulgowska-Zgrzywa, M., Sayegh, M.A., Milko, J., Danielewicz, J., Nannou, T.K., and Lester, S.P. "The performance of a heat pipe based solar $\mathrm{PV} / \mathrm{T}$ roof collector and its potential contribution in district heating applications", Energy, 136, pp. 117125 (2017).

24. Long, H., Chow, T.T., and Ji, J. "Building-integrated heat pipe photovoltaic/thermal system for use in Hong Kong", Solar Energy, 155, pp. 1084-1091 (2017).

25. He, W., Hong, X., Zhao, X., Zhang, X., Shen, J., and Ji, J. "Theoretical investigation of the thermal performance of a novel solar loop-heat-pipe facadebased heat pump water heating system", Energy and Buildings, 77, pp. 180-191 (2014).

26. Zhang, X., Zhao, X., Xu, J., and Yu, X. "Characterization of a solar photovoltaic/loop-heat-pipe heat pump water heating system", Applied Energy, 102, pp. 12291245 (2013).

27. Chaudhry, H.N., Hughes, B.R., and Ghani, S.A. "A review of heat pipe systems for heat recovery and renewable energy applications", Renewable and Sustainable Energy Reviews, 16(4), pp. 2249-2259 (2012).

28. Maydanik, Y.F. "Loop heat pipes", Applied Thermal Engineering, 25(5-6), pp. 635-657 (2005).

29. https://www.energy.gov/eere/solar/articles/solarradiation-basics.

30. https://globalsolaratlas.info/downloads/world.

31. Chi, S.W., Heat Pipe Theory and Practice: A Source Book, Hemisphere Pub. Corp. (1976).

32. Duffie, J.A. and Beckman, W.A., Solar Engineering of Thermal Processes, John Wiley \& Sons (2013).

33. Azad, E. "Assessment of three types of heat pipe solar collectors", Renewable and Sustainable Energy Reviews, 16(5), pp. 2833-2838 (2012).

34. https://www.energy.gov/eere/amo/combined-heatand-power-basics.

35. Herold, K.E., Radermacher, R., and Klein, S.A., Absorption Chillers and Heat Pumps, CRC press (2016).

36. Faghri, A., Heat Pipe Science and Technology, Global Digital Press (1995).

37. Cotter, T.P., Theory of Heat Pipes (No. LA-3246), Los Alamos Scientific Lab., Univ. of California, N. Mex. (1965).

\section{Appendix}

\section{Heat pipe theory}

Heat transfer by heat pipes is one of the fastest and most efficient methods. Heat pipes are highly conductive heat transfer devices. They use the latent heat of the working fluids for efficient heat transfer. The operation of LHPs is based on the same physical processes as those used in conventional heat pipes. However, they are organized in quite a different way. For further details, please refer to $[9,22,27,28,31,32,36,37]$.

\section{Biographies}

Vahid Beygzadeh received his BSc, MSc, and $\mathrm{PhD}$ degrees in Mechanical Engineering from the Urmia University (2010), Tabriz University (2012), and Urmia University of Technology (2018), respectively. His research interests include energy systems and heat transfer.

Shahram Khalilarya received his BSc, MSc, and $\mathrm{PhD}$ degrees in Mechanical Engineering from Tabriz University (1987), Tabriz University (1990), and Bath University (2001), respectively. He is currently an academic staff member at the Department of Mechanical Engineering at the Urmia University. His research interests include internal combustion engines and energy systems.

Iraj Mirzaee received his BSc, MSc, and PhD degrees in Mechanical Engineering from Ferdowsi University of Mashhad (1986), Isfahan University of Technology (1989), and Bath University (1997), respectively. He is currently an academic staff member at the Department of Mechanical Engineering at the Urmia University. His research interests include heat transfer and fluid mechanics.

Gholamreza Miri received his BSc and MSc degrees in Mechanical Engineering from Tabriz University in 1996 and 1998, respectively. His research interests include heat transfer and fluid mechanics.

Vahid Zare received his BSc, MSc, and $\mathrm{PhD}$ degrees in Mechanical Engineering from the Tabriz University in 2005, 2008, and 2013, respectively. He is currently an academic staff member at the Department of Mechanical Engineering at Urmia University of Technology. His research interests include exergy and fuel cells. 